\title{
E-Cash management System in the Public Sector in Sri Lanka: With Special Reference to the Ministry of Public Administration \& Home Affairs
}

\author{
Tharaka Liyanapathirana $^{1} \&$ R. P. C. Ranjani ${ }^{2}$ \\ ${ }^{1}$ University of Kelaniya, Sri Lanka \\ ${ }^{2}$ Department of Finance, University of Kelaniya, Sri Lanka \\ Correspondence: Tharaka Liyanapathirana, University of Kelaniya, Sri Lanka. E-mail: \\ tharakaliyanapathirana@gmail.com
}

Received: April 25, 2017

Accepted: May 18, 2017 Online Published: May 29, 2017

doi:10.5539/jms.v7n2p152

URL: http://doi.org/10.5539/jms.v7n2p152

\begin{abstract}
E-cash Management System enhances cash management in the private sector and the public sector in a fast pace of organizational environment change. Though it has not a universal framework for e-cash management, the public sector in many countries has provided its usefulness by dint of their results of application. Concurrently, the public sector in Sri Lanka has also initiated e-cash management at ministerial and departmental levels parallel to the existing setup. Despite many attempts made in improving e-cash management system in the public sector, little progress has been made. However, there is a lack of research on e-cash management in the public sector in Sri Lanka. Thus, this study focuses to fill the gap in this regard. This study seeks to contribute knowledge in this area by addressing related questions. The first research question is as follows: Despite many reformsmade in the administration system in the public sector, whydo the issues in respect of e-cash management system abide or persist or prevail to be addressed? Secondly, what are the factors that have adversely affected the progress of e-cash management? Hence the study was carried out to elite answer to the aforementioned questions.Combinations of Qualitative and Quantitative research strategies were applied in the research process which is commonly known as mixed method research. Random sampling method was applied. Samples of 500 managers in the public sector were selected and only 317 responded. Data were collected by self-administered Questionnaire and interviewed concurrently. Using the data from the survey analyses was completed. The results of the study revealed that the existing level of e-cash management owing to administrative reforms and implementations have not effectively addressed the deep-rooted social, political and cultural issues which pose as crucial barriers for the success of e-cash management.
\end{abstract}

Keywords: e-cash, e-cash management, e-public sector, e-services, national policy

\section{Background}

The public sector performance in the global context is becoming an importantaspect of gradual growth in the developed and the developing countries. Contemporary public sector organizations play more dynamic roles than the traditional liner career in public sector organizations. In concurrence with the winds of change across the globe, the public sector organizations have commenced to adopt contemporary cash management practices and managers increasingly take up responsibility to manage their public resources. Thus, managers in the public sector organizations and the employees need to play their roles in a dynamic organizational environment with many challenges within and outside the organization. Presently, a fast pace of work environment is effecting enduring or dealing with deadlines and chronic pressure on high performance demand apropos (of) effecting changes in cash management.

In this context, cash management in Sri Lanka needs to play an important role in the Public Sector. The structure pertaining to cash management in Sri Lanka consists of the following structural components: the executive president enjoys executive powers; the parliament enjoys fiscal powers, while the central bank is assigned monetary policy matters, while the Treasury coordinates the budgetary matters, once it is passed by parliament. Further, in Sri Lanka the president opts to be the Minister of Finance under whose purview the national Treasury functions. Thus, there is a considerable centralization of power pertaining to economic and budgetary affairs in Sri Lanka. 
The Ministry of Finance and Planning (MFP) of Sri Lanka presently operates under the Executive President who isvestedwith the powers of the Minister of Finance under the constitution (1978). Therefore, this ministry is in charge of formulating the national economic and financial policies and strategies of the government for the country. The formulation of fiscal policies and macro-economic policy management, preparation of national budget, management of financial resources, management of national tax policies, and government revenue have supervened (befallen) within this Ministry. An effective coordination is expected within the barrier ofthe Treasury coming under the Ministry of Finance (MF). All of these functions that come under the ministry occur within the purview of the Executive President (EP). Hence, the high degree of centralization of economic and financial authority comes under the aegis or auspices of the executive president.

The central bank is in charge of the formulation of monetary policies and the overall macro-economic management for the country. By implication, therefore the government is expected to ensureefficient implementation of the both national budget and good management of financial resources for the socio economic progress of the country. In this setting, the Treasury comes under the Ministry of Finance and Planning (MFP) which is under the President, who is the head of the executive branch of the government. A team of officials who espouse the cause in the ministry of finance is positioned for the smooth functioning of the ministry. This team includes a Minister for Finance, and a Deputy Minister of Finance, who are elected politicians while the Secretary to the Treasury and his deputies are civil administrative officers. They are assisted by a team of professionals in charge of the respective divisions of the treasury such as finance, economic affairs, planning, banking, and administration.

Teofilovic (2002) explained that the very complex structure and functions related to economy, finance, policy management which call for efficient co-ordination for implementation of the budget and good management of financial resources for economic development of the country. Government spending agencies must be provided with necessary funds needed to implement the budget in a timely manner in order to achieve the goals and objectives set out at national level. In the domain of public sector financial management for effective implementation in order to achieve the set goals and objectives, and it is imperative that the cost of government borrowing, where necessary be minimized and work for the sound management of financial resources or assets and liabilities. United Nation Program (2010), emphasized that it is a critical requirement, in the process of management of good governance. In the overall financial management as implied here, in respect of the work of the government, it entails by implication that important functions such as the formulation of the fiscal policy, budget preparation and budget execution, management of financial operation, accounting, and auditing. These functions have assumed critical importance in theday to day operational work of the government, in order to ensure effectiveness and efficiency.

Parente \& Mendez (1995) stated that when focusing on the financial management functions stated above, the specific objectives involved in management of public finance are namely, cash management, management of government bank accounts, financial planning, forecasting of cash flows, public debt management and the administration of foreign grants and counterpart funds, emanating (issuing) from international aid agencies and the financial assets. In order to carry out these specific activities of public finance management, the organizational arrangement, distribution of responsibilities in the institutional setting in Sri Lankavary considerably, as- compared to those of other countries. In this context, the Treasury in Sri Lanka mainly involves all its affairs in cash management functions with the Central Bank, Government and Spending Agencies as well. Since, the inception of the Central Bank in 1949, it plays the role in apprising the government in all monetary matters - formulating, managing monetary and banking operations of the country. In this context, the Ministry of Public Administration and Home Affairs with its operational mission is designed and dedicated to efficient and effective public services and the protection of citizens' rights. Consequently, the ministry has adopted to follow best practices, in the delivery of public service to the general publicof Sri Lanka. Furthermore, effective service delivery, service standards, timely delivery, commitment to responsibility, observing rules and regulations, ensuring transparency, accountability, efficiency, effectiveness in public services and readiness to address grievances and to offer redress to the public are the main considerations. The Ministry of public administration and home affairs (MPAHA), in conformity with the directives of the cabinet of ministers, has taken steps accordingly to implement the aforementioned policy initiatives.

\section{Literature Review}

This literature review aims to create theoretical approaches and discover findings from evaluation of public financial management, budgetary management, cash management in Sri Lanka and to find international financial management information system to identify knowledge gaps and show how to fit them in this research. Ranasinghe \& Fonseka (2011) explain thata literature review includes academic and technical articles, 
development of practitioner guides, manuals, handbooks, and web sites. The literature review seeks to address two sets of information: an overview of the models and approaches, adopted for research and a review of thefinancial management (FM), budgetary management, (BM), cash management (CM), and international financial management information system (IFMIS). Simson et al. (2011), state that in introducing public financial management literature, it focuses on the public financial management processes that are structured around the budget cycle.

Allen et al. (2004), states that, there is no universal consensus regarding the stages of the Public Financial Management. A review of the literature on PFM reforms shows that there is no universally agreed definition of PFM either. The narrowest definition confines PFM to downstream activities of budget execution, control, accounting, reporting, monitoring, and evaluation. Rosen (2002) refers to the definition describing PFM as the taxing, spending and debt management of the government, which influence resource allocation and income in a country distribution. The spending part covers the budget cycle, including budget preparation, internal controls, accounting, internal and external audit, procurement, monitoring and reporting arrangements.

Muttukrishna (2007) refers to the government budget aiming that the accountability and transparency are two debatable aspects of the budget process and indeed it is a part of the democratic governance of Sri Lanka. The writer emphasizes that the Sri Lankan budget process has four stages, namely, formulation of budget proposals, legislation, implementation, and auditing. Government responsibilities are to ensure that the public money is used in an accountable manner and people have the right to know how government spends their money. The Guidelines for public expenditure management (2005) states that the budgetary management processes are very important to policy makers on the feasibility and desirability of specific public financial management.

Williams (2004) delineated that the conceptually cash management in the larger context of financial management, refers to managing currency notes, coins and deposits held by the government for the purpose of public administration and public management of resource use as required by government institutions from banks and other financial institutions. Lienert (2008) defined the cash equivalents as highly liquid investments that are readily convertible to cash on hand for spending on current needs. The major focus of this study is on managing government cash on hand for public administrative purposes. As per Lesire et al. (2008), stated that the government treasury is involved and isalsoconcerned with managing cash equivalent.

According to the ICTA Survey (2011) e-Government could be defined broadly as use of Information and Communications Technology (ICT) to promote more efficient and effective government, facilitate more accessible government services and allow to access information and make government more accountable to citizens.According to Gunathunge (2003), studies performed by Sri Lankan researchers, have disclosed that there have been numerous failures in developing information systems for organizations in Sri Lanka. This is mainly due to the ignorance of the social context within the information systems. Hence, Table 1 as follows the present status of cash management system in Sri Lanka.

Table 1. Present status of cash management system in Sri Lanka

\begin{tabular}{|c|c|c|}
\hline In General & & $\begin{array}{ll}\text { - } & \text { Manual Process } \\
\text { - } & \text { Use of the Ms-Excel } \\
\text { - } & \text { Slower Processing Speed } \\
\text { - } & \text { Test Base Interface } \\
\text { - } & \text { Lack of Robust System } \\
\text { - } & \text { No Codified Practices } \\
\end{array}$ \\
\hline Receipt Management & & $\begin{array}{ll}\text { - } & \text { Use of the CIGAS } \\
\text { - } & \text { Pay Taxes-By Public } \\
\text { - } & \text { Collect Taxes-By Revenue Agencies } \\
\text { - } & \text { Record Revenue Data in CIGAS } \\
\text { - } & \text { Significant Variations in Revenue Forecasting } \\
\text { - } & \text { Need for Bank and Revenue Reconciliation } \\
\text { - } & \text { Using Excel Sheets and Manual Introduces Errors }\end{array}$ \\
\hline $\begin{array}{l}\text { Commitment and } \\
\text { Management }\end{array}$ & Payment & $\begin{array}{l}\text { - Use of the CIGAS } \\
\text { - } \quad \text { Recording of the Expenditure } \\
\text { - } \\
\text { - Pmalgamated of Three Process Commitment, Payment and } \\
\text { - } \quad \text { Purchase Requisitions are not Registered } \\
\text { - } \quad \text { Manual Process can Introduce Errors and Duplicate Data }\end{array}$ \\
\hline
\end{tabular}




\begin{tabular}{lll}
\hline Budget Authorization & - & Manual Processes \\
& - & Slower Processing Speed \\
& - & No Computer Application for Integration between Preparation \\
& and Execution \\
\hline Budget Preparation & - Use of the Ms-Excel \\
- & Manual Processes \\
- & Slower Processing Speed \\
- & Test Base Interface \\
- & No Computer Application for Integration between Preparation \\
& and Execution \\
- & Does not Cater for Cost Drivers \\
- Fragmented Information Sources and no Uniformity in the & Classification \\
\hline
\end{tabular}

Source: Developed by Researcher.

\section{Problem Statement}

It is possible for this research study to point out that these specific factors that must be addressed to implement an e-cash management system in the public sector in Sri Lanka as well as augmenting or intensifying providing encouragement and facilitation for new research areas which are hither to nit dealt with or processed national policy.

It is observed that in public discussions and debates in parliament, development projects for which money has been authorized by parliament to the Treasury, is not usually allocated within theallotted time schedule. (Budget speech, 2014) This report further, states that there are delays in the release of funds by the Treasury. In technical language the reason for this delay is issuance of the imprest (timely release of funds) by the treasury to the respective ministry. Given this complex intuitional baseinvolved in cash management of the government of Sri Lanka, its impact on the Ministry, the need for rationalization of cash management is an essential step, in practising good governance. Agree (2000),mentioned that the governments of various countries have in recent years adopted the principles of good governance, which entails responsibility, public accountability and transparency in managing public finance, in the public sector, for timely implementation of development projects. Wickramasinghe (2003) highlighted that as the process of socio-economic development under direct government involvement; itpresently gathers momentum in Sri Lanka with the peace and development in the country, after the cessation (termination) of the terrorist conflict in the north. The need for adopting a new public management system in the practice of public finance is both necessary and urgent in the Sri Lankan context. The rationalization of cash management turns out to be a key factor in this context. Though a study of cash management system of the entire public sector in Sri Lanka is desirable, it is well beyond the resources available to the present research to do so. Therefore, the Ministry of Public Administration and Home Affairs (MPAHA) is selected for an in-depth study as it is the largest ministry covering all parts of the country in the public service delivery.

However, government operation still deals with a very insignificant proportion of economic activity. Together with the high fiscal deficit and high levels of domestic borrowing, and limitation of private sector activity, it has challenged views on sustainable levels of economic growth and stable price to reduce the fiscal deficit. The government is attempting to increase revenue, control of expenditure and improve public sector efficiency. Despite many efforts attempted in order to improve efficiency and effectiveness of cash management system in the application of e-cash management system in the public sector, concurrently there are several criticisms leveled at, with regard to cumbersome processes and procedures, bulky document units, political interfaces, inherent lethargic attitudes and lengthy processes, all of which have adversely affected application of e-cash management slowing down the present cash management system in the public sector in Sri Lanka.

Thus, this study attempts to examine factors that could be much hoped to prompt anticipated effect on efficiency and effectiveness of e-cash management systems in the public sector in Sri Lanka. Accordingly, the research question is to define as to what extent application of e-cash management system in public sector organizations improves its effectiveness and efficiency.

\subsection{Justification of the Problem Statement}

In the Ministry of Public Administration and Home affairs, cash management is envisaged to follow the best and the up-to-date practices of cash flow and cash equivalent management throughout the system year after year. Cash management policies are directed at all aspects of collection of revenue, disbursement, investment and 
debit management. According to the Ministry of Public Administration and Home Affairs progress report (2015) and Activity Plan of 2016, focusing on the primary (core) concern of the Ministry of Public Administration and Home Affairs (MPAHA) as the Centre of civil administration is to facilitate and coordinate service-related functions of public administration, district administration, divisional administration up to village level administration, and civil registration and employee welfare. These activities involve collecting revenue by way of fees and charges from the public and spending diverse on public services. The ministry deals with a number of other functional areas such as public policy-making, organizational management, human resource management and institutional development. The Ministry in recent years has adopted the concept of e-governance and best practices, targeting social and economic development in accordance with the national priorities set out by the government.

Thus, the primary aim of this study would be to focus on Cash management system in the Ministry of Public Administration and Home Affairs (MPAHA) with a view to evaluate its efficiency and effectiveness in ensuring, transparency and accountability in the delivery of public services for customer/service provider's satisfaction. The study basically poses the question as to why cash management in the Sri Lankan context is a major problem for the government and why it attempts to study and identify the reasons and causes for the existing state of affairs. The study would then attempt to explore the prospects and possible methods of resolving this problem using new systems of international standards. It was stated that both the existing cash-based financial management system and public finance processes were inadequate for effective public management, although cash-based financial management system was effective for limiting expenditure for a given year. It focused on control over the expenditure of public money in the current year. Hence, this study focuses on the following issues with regard to e-cash management.

\section{Research Questions}

- What is the existing e-cash management system racticed in the public sector in Sri Lanka?

- What is the most effective e-cash management system implemented in the public sector in Sri Lanka?

- What are the failure factors of e-cash management system in the public sector in Sri Lanka?

- What are the success factors of e-cash management system in the public sector in Sri Lanka?

- How does e-cash management affect organizational effectiveness and efficiency with regard to cash management?

- What suitable policy recommendations could be made regarding improvements not yet envisaged?

\subsection{Developing a Conceptual Framework for this Study}

The development of a conceptual framework for this studyis shown in Figure 1 and it is constructed based on the analysis of literature. In order to select the most relevant variables for testing, a comprehensive review of the empirical research on success (strength) factors and issues (problem/weakness /failure) regarding implementation of cash management systemin the public sector were considered. The research model identifies the success (strength) factors and failure (weakness) factors that lead to implementation of cash management systemfor public entities. Failure (weakness) factors are considered here because most of the variables included are failure (weakness) factors which could be mitigated as risks associated in this process. The researcher has summarized the identificationof success (strengths) and failure (weaknesses) from the previous researches conductedglobally in public sector organizations. This research shifted each one from the common factors and categorized themin order to carry out the research in Sri Lankan public bodies.These five variables finally are considered as implementation ofe-cash management systemfor success of the public sector. Further, the researcher identified the relationship betweene-cash management system success (strength) and failure (weakness) factors. Subsequently, based on the aforementioned factors, the framework is developed. The model identifies the best practices out of five groups of success (strength) factors and four groups of preventive of failure (weakness) factors. The success (strength) factors are grouped as Organizational, Strategic Management, Operational, Technical, and Service Provider. Diversity of factors (moderate variables) is identified as failure (weakness) factors and all of them are grouped together under Resistance, Economy, Risks, and Inadequacy. 


\section{The Conceptual Framework}

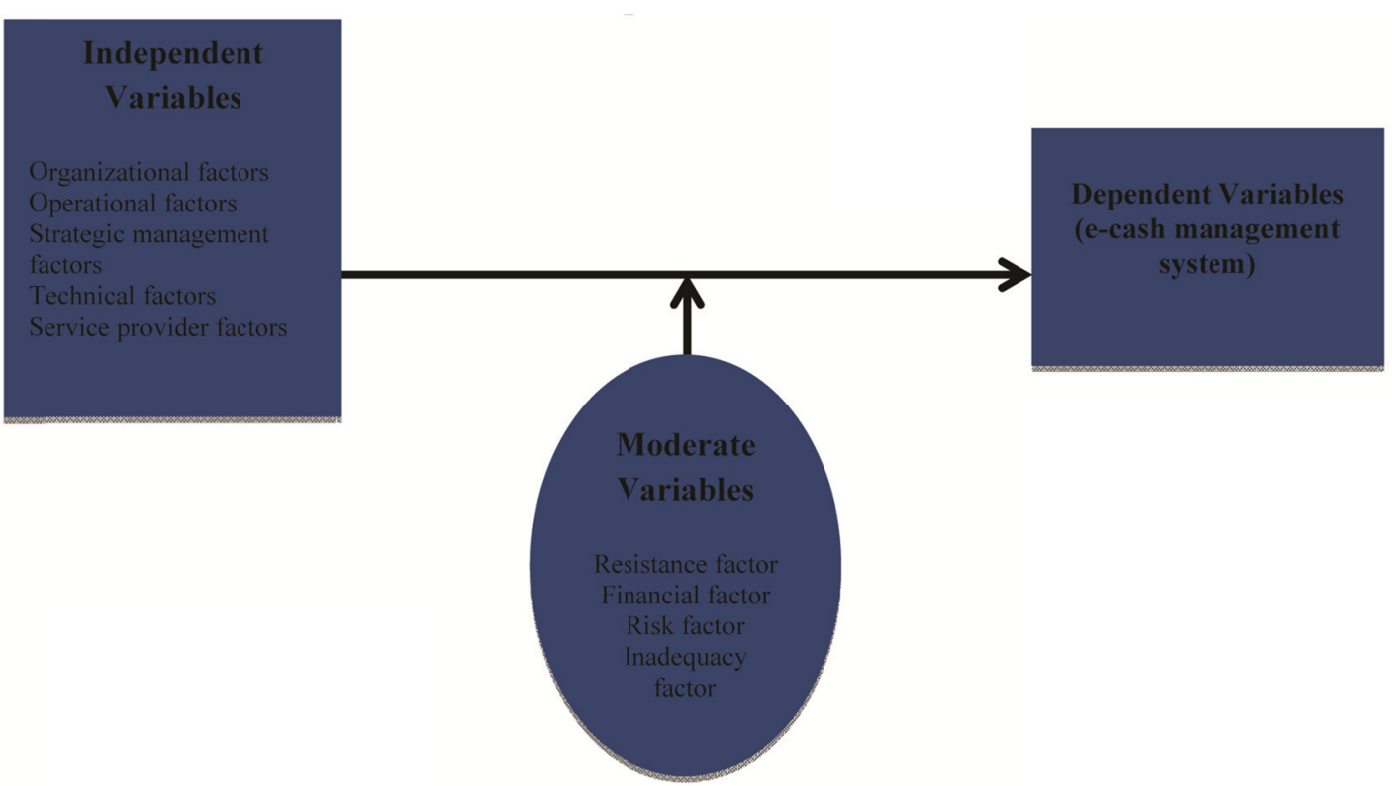

Figure 1. The proposed conceptual framework

Source: Developed by researcher.

\subsection{Objectives of the Study}

The objectives of this research are as follows:

Objective 1. To find out the prevailing e-cash management system in the public sector in Sri Lanka

Objective 2. To find out the most effective e-cash management system in the public sector in Sri Lanka

Objective 3. To find out failure factors adversely affecting e-cash management system in the public sector in Sri Lanka

Objective 4. To find out the success factors affecting e-cash management system in the public sector in Sri Lanka

Objective 5. To find out e-cash management affecting organizational effectiveness and efficiency with regard to cash management of e-cash management

Objective 6. To formulate suitable policy recommendations regarding improvement not yet implemented

\subsection{Hypothesis Development}

It is based on theproposed conceptualresearch framework to identify relevant factors for cash management system in the Ministry of Public Administration and Home Affairs (MPAHA) in Sri Lanka. According to the conceptual framework (conceptual model) similar characteristic variables are grouped together and hypotheses were introduced for those groups known as factors.

Hypothesis 1

Organizational factors positively affect cash management system success.

Hypothesis 2

Strategic Management factors positively affectcash management system success.

Hypothesis 3

Operational factors positively affectsuccess of cash management system.

Hypothesis 4

Technical factors positively affect success of cash management system.

Hypothesis 5

Service Provider factors positively affectcash management system success.

Hypothesis 6 
Prevention of Resistance factors moderatecash management system success.

Hypothesis 7

Prevention of Financial (economy) factors moderatecash management system success.

Hypothesis 8

Prevention of Risk factors moderatecash management system success.

Hypothesis 9

Prevention of Inadequacy factors moderatecash management system success.

\section{Significance of the Study}

It is claimed that the public sector organizations play a significant role in providing cash management services to the nation. Sri Lanka as a welfare state provides public sector cash management services in order to deliver such services from the national level to the grassroots level is committed to fulfillment of the aspirations of the general public. Since, Sri Lanka's gaining independence; the Central Bank Annual Report (2015) of Sri Lanka shows that cash management of the public sector organizations changes annually in the ascending order of magnitude. Most of the public sector organizations utilize public funds for their operations and other development work. The public expects that management system in public spending organization be effective and efficient in cash management system for their day-to-day needs. Public spending agencies need to meet the aspirations as per the state policy of utilizing cash management complying with the rules and the regulations which govern the public sector.

This thesis is compiled on the assumption that an envisioned system of government reflects the specific situation that the country faces and out of which a relevant system could be developed. Any attempt to develop a public sector cash management system in Sri Lanka, must be based on these specifics. In the literature review related to this topic, it indicates that modernizing cash management system needs to be based on certain assumptions. The main objective of the study is to focus on the existing cash management system in the Ministry of Public Administration and Home Affairs (MPAHA) in Sri Lanka and to identify strengths and weaknesses of the system. In other words, it implies that cash management currently employed could be suitably transformed (re-modeled) to offer solutions to resolve the problems utilizing wherever possible adopting an e-cash management system appropriate to the Sri Lankan economy in general and the national policy in particular. As per the Central Bank Annual Report (2015), Sri Lanka presently needs transforming the country to a high performing economy to generate per capita US $\$ 5000$ level by the year, 2020 from the present level of US $\$ 2600$.To achieve this aim of the national revenue, the public sector of Sri Lanka is expected to play a strategic role in adopting new policies and procedures to modernize the entire system of cash management. Such a rapid rate of socio-economic development summons modernization of the Sri Lankan public sector cash management system which is ridden with systems that are not favorable for rapid development as per the current vision and mission of the government. The government of Sri Lanka is to be responsible for formulating, implementing and improving the e-cash management system of public policies. Also e-cash management system is significant to organizational efficiency and effectiveness as well.

\section{Methodology}

\subsection{Population}

Population is an overall pool of elements such as the entire group of people, events or things under a study (Sekaran \& Bougie, 2014). The Population for this study consists of those who use application of cash management system in Sri Lanka.

\subsection{Target Population}

The target population for information relevant to this research includes all project members and those who are using cash management system in public sector organizations.

\subsection{Sample}

Sampling is the process of selecting a sufficient number of elements from the population (Sekaran \& Bougie, 2014). The population refers to an entire group of people, events or things of interest that the researcher refers to investigate while an element refers to a single member of that population (Sekaran \& Bougie, 2014).In addition, this group of sample is used because it is impossible to study the entire population of government organizations due to limitations of time and cost. Further, Sekaran \& Bougie (2014) posit that studying a sample will lead to reliable results because fatigue is reduced, resulting in fewer errors in collecting and analyzing data. 


\subsubsection{Sampling Procedure}

In carrying out this study, a survey research method was adopted. The research is covered for the application of the cash management system in Sri Lanka .This study explored three main managerial levels such as: Top management, Middle level management and Lower level management in the Sri Lankan public sector. The objective of the survey is to make inferences about apopulation based on the sample (Creswell et al., 2011). Most studies are faced with such limitation as resources (funds and times). Therefore, it is not practical to survey the whole population. Hence, sampling is the next best option to generalize the findings over the population. The sampling is a process of selecting a suitable number of elements from the population and it can lead to more reliable results and fewer errors in data collections (Field, 2009; Sekaran \& Bougie, 2014).

\subsubsection{Sample Selection}

Gonzalez et al. (2005) recognized the sample size considered as 20 percent of the population. This percentage was selectedafter reviewing similar researches in other countries. As a result, the public sector organizations (ministries, departments, district secretaries, and other institutions) were expectedto participate in this research. Most of the systemusers were very supportive but some were unenthusiastic or unwillingto participate as they are busy with their own work.

\subsubsection{Sampling Frame}

For this study, the sample is drawn from various sectorsof institutions andselections were completed from those that put the cash managementsystem into operation in Sri Lanka. In relation to population size of the two thousandfive hundred (2500), a sample of 500 was targeted for this study. Stratification process was carried out in order to sample the sector individually. Then, a simple random sampling was used to make sure that sampling units have equal chance to be selected (Sekaran \& Bougie, 2014).

\subsubsection{Sampling Element}

Sampling element refers to a single unit or set of elements in a sample. The Sampling element in the study comprised of topmanagement, middle management and lower level management (Secretary, Additional Secretary, Chief financial officers, Chief accountants, Head of departments, System manager, ITmanager and Accountants). This managerial group was chosen on the basis that they form a device to bridge the gap between the top manager as executive and the operatives at the lower level (Chatterjee et al., 1992). The middle manager is equipped with sufficient knowledge of the strategic vision and is substantially knowledgeable on the technical aspects of the lower case of management operation. Despite the earlier claim in (2007), it was identified that the lower level employeesare knowledgeable or well-informed regarding a lot of information technology (IT) compared to the knowledge of the manager and in most literatureit is argued that, normally the managers have a more cogent insight of the organization's overall IT set-up and cash management policies. The managers are also involved in acquiring, evaluating, purchasing, implementing and they maintain cash management in an organization (Thong, 1999). Therefore, responses from this group present valid samples in the context of this study.

\section{Questionnaire Development}

This questionnaire was developed from various existing instruments to enhance the variability of the measure. The questionnaire was subjected to two stages of pilot testing before it was finalized and distributed to the respondents. Some have argued that the use of mailed questionnaires is disadvantageous due to its poor response rates and the quality of the responses (Kerlinger \& Lee, 2000). However, since issues of time and cost weretaken into consideration, it was found that it is justifiable to use this method.

\section{Data Collection}

Data for the study were collected from primary sources. Additionally, to further enhance response rate, cover letters from the Ministry and the University were attached in assuring the respondent's confidentiality of their responses and requesting their honest opinion (Dillman, 2011).

Hence, combinations of Qualitative and Quantitative research strategies were applied in the research process which is commonly known as mixed method research. Random sampling method was applied. Samples of 500 managers in the public sector were selected and only 317 responded. Data were collected by self-administered Questionnaire and interviewed concurrently. 


\section{Method of Analysis}

9.1 Result and Analysis

Table 2. Profile of the Respondents

\begin{tabular}{|c|c|c|c|}
\hline \multirow{6}{*}{$\begin{array}{l}\text { Description } \\
\text { Organization }\end{array}$} & & Frequency & Valid Percent \\
\hline & Divisional Secretariats & 136 & 42.9 \\
\hline & District/Secretariats & 25 & 7.9 \\
\hline & Dept./otherintuitions & 101 & 31.9 \\
\hline & Ministry & 55 & 17.4 \\
\hline & Total & 317 & 100.0 \\
\hline \multirow[t]{6}{*}{ Position } & DS/Ads/Acc/Adp & 160 & 50.5 \\
\hline & Dis Secretariats & 25 & 7.9 \\
\hline & $\mathrm{HD}$ & 67 & 21.1 \\
\hline & $\mathrm{CFO} / \mathrm{ADs} / \mathrm{DG}$ & 55 & 17.4 \\
\hline & $\mathrm{Sec}$ & 10 & 3.2 \\
\hline & Total & 317 & 100.0 \\
\hline \multirow[t]{5}{*}{ Education } & Graduate & 104 & 32.8 \\
\hline & Degree and Dip & 7 & 2.2 \\
\hline & Postgrads & 202 & 63.7 \\
\hline & MPhil & 4 & 1.3 \\
\hline & Total & 317 & 100.0 \\
\hline \multirow[t]{4}{*}{ Age } & $30-40$ & 50 & 15.8 \\
\hline & $41-50$ & 149 & 47.0 \\
\hline & $51-60$ & 118 & 37.2 \\
\hline & Total & 317 & 100.0 \\
\hline \multirow[t]{5}{*}{ Responsibility } & TopMgt & 56 & 17.7 \\
\hline & MidMgt & 138 & 43.5 \\
\hline & LowMgt & 104 & 32.8 \\
\hline & other & 19 & 6.0 \\
\hline & Total & 317 & 100.0 \\
\hline \multirow[t]{5}{*}{ Contribution } & Tem Member & 6 & 1.9 \\
\hline & Data Gathering & 256 & 80.8 \\
\hline & System Run & 54 & 17.0 \\
\hline & Other & 1 & .3 \\
\hline & Total & 317 & 100.0 \\
\hline
\end{tabular}

Source: Survey Data.

Analysis of data in Table 5 indicated that Questionnaire survey there were 317 respondents, Table 2 shows that the respondents' demographic details when organizations are taken into consideration as insiders and among them 42.9 percent were from divisional secretariats, 31.9 percent were from department/other institutions, 17.4 percent were with a ministry and 7.9 percent were from district secretariats.According to Table 5.2 it is shown that in there exists a considerable number with University education. Amongst them 63.7 percent were postgraduates, 32.8 percent were graduates, 2.2 percent were with a degree and diploma and 1.3 percent were with a master of philosophy degree.By reviewing the age of the respondents 47 percent were in the 41-50 age category, 37.2 percent belonged to 51-60 age range and 15.8percent were from 30-40 age group.

43.5 percent belonged to middle management, and such indication is again not surprising, since most of the middle management is "running the show" in most government organizations and always they are available in the office to attend to theday-to-day conducting of programmers with reference to application of cash management system. This is not surprising since the title of this study is organized to financial area. Secondly, 32.8 percent of the respondents have indicated that they belong to lower level management position. 17.7 percent were with the top management and 6percent belonged to those in other areas of responsibility.

\section{Variables}

A variable is an observable item which can assume different values (Smith, 2015; Sekaran \& Bougie, 2014). These values can be measured directly or if indirectly, through the use of proxy or substituted variables. There are three types of variables in this study such as: dependent variables, independent or explanatory variables, and moderating variables. 


\subsection{Dependent Variables}

Dependent variables are variables that are of primary interest to the researcher (Sekaran \& Bougie, 2014) and their variability is explained or influenced by independent variables. In this research, the dependent variable is the application of the cash management system. There are five (5) measurements that will be used for application of the cash management system and as such, this study uses all — scope, quality, communication, time and cost. The description of all the measurements is based on the results of the empirical researches that have used similar measurements.

\subsection{Independent Variables}

An independent variable is one that influences the dependent variable, either positively or negatively. A unit increase in the independent variable may cause an increase or decrease in the dependent variable (Sekaran \& Bougie, 2014). The independent variables in this study are such as: organizational, operational, strategic management, technical and service factors. This will provide a more thorough assessment on cash management system compliance. Furthermore, these multiple indicators will reduce the limitation of results of study that rely on selective indicators which may introduce bias to the result.

Table 3. Correlation among the independent variables

\begin{tabular}{lllllll}
\hline & Cash Mgt & $\begin{array}{l}\text { Organization } \\
\text { Factor }\end{array}$ & Strategic Mgt & $\begin{array}{l}\text { Operational } \\
\text { Factor }\end{array}$ & $\begin{array}{l}\text { Technical } \\
\text { Service } \\
\text { Provider }\end{array}$ \\
\hline Cash Mgt & 1.000 & & & & & \\
Organizational Factor & .538 & 1.000 & & & \\
Strategic Mgt & .441 & .734 & 1.000 & 1.000 & & \\
Operational Factor & .484 & .100 & .000 & .158 & 1.000 & .852 \\
Technical & .548 & .605 & .769 & .250 & .000 \\
Service Provider & .648 & .558 & .668 & & &
\end{tabular}

\subsection{Moderating Variable}

A moderating variable is a variable that has a strong contingent effect on the influence of the independent variable on the dependent variable. The presence of moderating variables will modify the independent-dependent variable relationship. This shows that it can either strengthen or weaken the relationship. In this study, the moderating variables are resistance, economy, risk, and inadequacy factors.

Table 4. Correlation among the moderating variables

\begin{tabular}{|c|c|c|c|c|}
\hline & Finance Factor & Resistance & Risk Factor & Inadequacy \\
\hline Finance Factor & 1.000 & & & \\
\hline Resistance & .346 & 1.000 & & \\
\hline Risk Factor & .524 & .524 & 1.000 & \\
\hline Inadequacy & .336 & .336 & .310 & 1.000 \\
\hline
\end{tabular}

Source: Survey Data.

Table 5. Summary of reliability variables understudy

\begin{tabular}{|c|c|c|c|c|c|}
\hline Construct & $\begin{array}{l}\text { Number } \\
\text { of Items }\end{array}$ & Cronbach's Alpha & $\mathrm{CR}$ & AVE & Factor loading \\
\hline Organizational factor & 5 & .958 & .917 & .735 & $(.842-.866)$ \\
\hline Strategic management factor & 4 & .983 & .848 & .582 & $(.740-.793)$ \\
\hline Operational factor & 4 & .964 & .840 & .567 & $(.749-.756)$ \\
\hline Technical factor & 4 & .957 & .919 & .739 & $(.842-.903)$ \\
\hline Service provider factor & 5 & .894 & .922 & .748 & $(.860-.894)$ \\
\hline Resistance factor & 5 & .815 & .867 & .621 & $(.754-.821)$ \\
\hline Financial/ Economy factor & 4 & .838 & .872 & .630 & $(.741-.861)$ \\
\hline Risk factor & 5 & .816 & .868 & .622 & $(.784-.800)$ \\
\hline Inadequacy factor & 5 & .786 & .845 & .577 & $(.735-.802)$ \\
\hline Cash management system (Efficiency) & 1 & .879 & .923 & .750 & $(.859-.877)$ \\
\hline Cash management system (Effectiveness) & 1 & .877 & .927 & .760 & $(.861-.877)$ \\
\hline
\end{tabular}


In the summary of reliability as shown in Table 5, it indicates that the items of the constructs are strongly correlated. This is evidenced by almost all the items (except one item that is loaded at 0.37 ) loaded at the desired value of above 0.50 . Convergent validity was evidenced further, by high CR and acceptable AVE threshold.

Table 6. Regression results of the cash management system

\begin{tabular}{llllll}
\hline Predictor & Sig. & $\mathrm{R}$ & $\mathrm{R}$ squared & $\begin{array}{l}\text { Adjusted } \\
\mathrm{R}^{2}\end{array}$ & $\mathrm{~F}$ \\
\hline (Constant) & .000 & & & & \\
Cash Mgt & .000 & .573 & .329 & .327 & 154.22 \\
Organization Factor & .000 & .538 & .290 & .287 & 128.448 \\
Strategic Mgt & .000 & .441 & .195 & .192 & 76.250 \\
Operational Factor & .000 & .484 & .234 & .322 & 96.418 \\
Technical & .000 & .548 & .300 & .298 & 135.05 \\
Service Provider & .000 & .648 & .420 & .418 & 154.22 \\
\hline
\end{tabular}

Source: Survey Data.

\subsection{Statistical Analysis for Quantitative Methods}

There are many types of statistical analyses that can be used in analyzing the data that was collected for this study. Among them, the regressions (R),coefficient determination $\left(\mathrm{R}^{2}\right)$, average variance extracted (AVE) are the most appropriate statistical analyses that can be used for this research as its objective is to examine the relationship, its effect and its interaction between independent variables, dependent variables and moderating variables that are of a continuous type.

Generally, there are three types of multiple regressions that can be used in statistical analysis, namely, standard multiple regression, stepwise multiple regression and hierarchical multiple regression. This study used the stepwise regression to analyze and explore a relationship between the dependent variable and the independent variable as well as the moderating variable.

This type of regression was chosen because it is a popular or well-known statistical method used in empirical research. The dependent variable was regressed together with the independent variables. Each independent variable was evaluated in terms of its predictive power as compared to other independent variables.

\section{Findings of the Study}

This study also made use of quantitative and qualitative analyses to get different perspectives and richer information on the topic under the study. Using more than one data collection method is useful in getting confirmatory evidence from both sources. The results from the quantitative and qualitative analyses revealed what the researcher anticipated as important elements for cash management system in the government organizations. Such benefits as confidence and e-cash management system compliance and its good reputation are among the blessing received from government organizations. Government organizations have implemented cash management system while proper monitoring is the biggest assert that is procured by adopting cash management practices. The planning and monitoring cash management practices are responsibilities of top management, middle management and lower level management which then are executed by all categories of the top management led by the chief accounting officers and accounting officers. To ensure effectiveness and efficiency, professional code of ethics should not merely be a statement of intent but must be institutionalized and incorporated in the working environment of the government organizations. If e-cash management system is properly implemented, good ethical practice can be a very powerful mechanism to sustain the effectiveness and efficiency of the government organizations although cash management practices do not measure up to that required standard. 
Table 7. Comparison of e-cash management functions

\begin{tabular}{|c|c|c|c|c|c|}
\hline $\begin{array}{l}\text { e-cash management } \\
\text { functions }\end{array}$ & New Zealand & Canada & Singapore & Sri Lanka & Applications \\
\hline Budget Preparation & $\begin{array}{l}\text { Electronic } \\
\text { Process }\end{array}$ & $\begin{array}{l}\text { Electronic } \\
\text { Process }\end{array}$ & Electronic Process & Manual Process & $\begin{array}{ll}\text { - } & \text { Use of the Ms-Excel } \\
\text { - } & \text { Manual Processes } \\
\text { - } & \text { Text Base Interface }\end{array}$ \\
\hline Budget Authorization & $\begin{array}{l}\text { Electronic } \\
\text { Process }\end{array}$ & $\begin{array}{l}\text { Electronic } \\
\text { Process }\end{array}$ & Electronic Process & Manual Process & - Manual Processes \\
\hline $\begin{array}{l}\text { Expenditure } \\
\text { management }\end{array}$ & $\begin{array}{l}\text { Electronic } \\
\text { Process }\end{array}$ & $\begin{array}{l}\text { Electronic } \\
\text { Process }\end{array}$ & Electronic Process & Manual Process & $\begin{array}{l}\text { - Use of the CIGAS } \\
\text { Recording of the } \\
\text { Expenditure }\end{array}$ \\
\hline Revenue Management & $\begin{array}{l}\text { Electronic } \\
\text { Process }\end{array}$ & $\begin{array}{l}\text { Electronic } \\
\text { Process }\end{array}$ & Electronic Process & Manual Process & $\begin{array}{ll}\text { - } & \text { Use of the CIGAS } \\
\text { - } & \text { Pay Taxes-By Public } \\
\text { - } & \text { Collect Taxes-By } \\
\text { - } & \text { Revenue Agencies } \\
\text { in CIGAS }\end{array}$ \\
\hline Cash management & $\begin{array}{l}\text { Electronic } \\
\text { Process }\end{array}$ & $\begin{array}{l}\text { Electronic } \\
\text { Process }\end{array}$ & Electronic Process & Manual Process & $\begin{array}{ll}\text { - } & \text { Manual Process } \\
\text { - } & \text { Use of the Ms-Excel } \\
\text { - } & \text { Text Base Interface }\end{array}$ \\
\hline Debit management & $\begin{array}{l}\text { Electronic } \\
\text { Process }\end{array}$ & $\begin{array}{l}\text { Electronic } \\
\text { Process }\end{array}$ & Electronic Process & Manual Process & $\begin{array}{ll}\text { - } & \text { Manual Process } \\
\text { - } & \text { Use of the Ms-Excel } \\
\text { - } & \text { Text Base Interface }\end{array}$ \\
\hline Fiscal Reporting & $\begin{array}{l}\text { Electronic } \\
\text { Process }\end{array}$ & $\begin{array}{l}\text { Electronic } \\
\text { Process }\end{array}$ & Electronic Process & Manual Process & $\begin{array}{ll}\text { - } & \text { Manual Process } \\
\text { - } & \text { Use of the Ms-Excel } \\
\text { - } & \text { Text Base Interface }\end{array}$ \\
\hline $\begin{array}{l}\text { Fixed Assets } \\
\text { management }\end{array}$ & $\begin{array}{l}\text { Electronic } \\
\text { Process }\end{array}$ & $\begin{array}{l}\text { Electronic } \\
\text { Process }\end{array}$ & Electronic Process & Manual Process & $\begin{array}{ll}\text { - } & \text { Manual Process } \\
\text { - } & \text { Use of the Ms-Excel } \\
\text { - } & \text { Text Base Interface }\end{array}$ \\
\hline $\begin{array}{l}\text { Carder Information } \\
\text { Management System }\end{array}$ & $\begin{array}{l}\text { Electronic } \\
\text { Process }\end{array}$ & $\begin{array}{l}\text { Electronic } \\
\text { Process }\end{array}$ & Electronic Process & Manual Process & $\begin{array}{ll}\text { - } & \text { Manual Process } \\
\text { - } & \text { Use of the Ms-Excel } \\
\text { - } & \text { Text Base Interface }\end{array}$ \\
\hline $\begin{array}{l}\text { Payroll management } \\
\text { System }\end{array}$ & $\begin{array}{l}\text { Electronic } \\
\text { Process }\end{array}$ & $\begin{array}{l}\text { Electronic } \\
\text { Process }\end{array}$ & Electronic Process & Manual Process & $\begin{array}{ll}\text { - } & \text { Manual Process } \\
\text { - } & \text { Use of the Ms-Excel } \\
\text { - } & \text { Text Base Interface }\end{array}$ \\
\hline $\begin{array}{l}\text { Internal Audit } \\
\text { Management System }\end{array}$ & $\begin{array}{l}\text { Electronic } \\
\text { Process }\end{array}$ & $\begin{array}{l}\text { Electronic } \\
\text { Process }\end{array}$ & Electronic Process & Manual Process & $\begin{array}{ll}\text { - } & \text { Manual Process } \\
\text { - } & \text { Use of the Ms-Excel } \\
\text { - } & \text { Text Base Interface }\end{array}$ \\
\hline
\end{tabular}

\section{Limitation of Study}

There are several limitations associated with the study. First, since the study was conducted in Sri Lanka, the results of this study may not be taken as a generalization for application in the context of other developed and developing countries which have different political, socio-cultural and economical governance factors.

This research is bounded by time, cost and availability of the resource constraints. For any exercise of research, there is always a practical limit placed on how much time that can be spent in the field work and data collection versus the time available for analysis. The researcher has utilized more secondary data due to time constraints in respect of collecting primary data or conducting interviews. The reliability of data could be assured to a satisfactory level.

This study included all public sector organizations that have their own modern application software packages as the intended survey would be limited to only these responding organizations.

The time period for data collection was limited to thirty six months ( $1^{\text {st }}$ Jun 2011 to $31^{\text {st }}$ of December 2014). The six months' time was indeed insufficient to collect data from the public sector organizations in Sri Lanka and usually stakeholders are not supportive for this type of academic research. It is a sad state of affairs related to the public sector in Sri Lanka.

\section{Conclusion}

There is a growing body of literature that ethics is becoming more and more important in the cash management system environment at the present time. This becomes more critical when laws and regulations including cash 
management system are unable to curb volatility in an uncertain government environment. In addition, government environment also is highly exposed to events of frauds, malpractices, corruptions and many other unethical practices that would ruin the government organization. Thus, this research provides evidence that, if the board of directors is committed to and takes substantive effort and action in creating an ethical working culture that follows good moral and proper conduct and good governance, it may provide hope for the best in cash management system in Sri Lanka.This application of cash management system is in a transformational juncture for future digital e-cash management platform of any country. Unhappy is the line of this transformation which will further eliminate representatives where only virtual (cybernetic) government organizations would remain stable. In Sri Lanka the support for the academic researchers is very much at a low ebb (tide) or retro gradation accepting for a few of the supportive top management, middle level management and lower level management. Others think that it is a time consuming activity for them and would not take into consideration (cogitate) about the useful resultderived from it.

\section{Future Research}

The area of e-cash management is a very important topic for researches. Since the government sector automations started thirteen years ago in Sri Lanka, it is still in a state of ingenuousness/ ingeniously or immaturity in terms of application of the cash management system. Therefore, overall government offices would not have much experience to respond to this type of research. In order to achieve advanced results, the same research should be repeated in a few years' time (after 3-5 years) to examine how application of the cash management system has benefited the public sector organizations and compare those results with the best practices that is identified by this research. However, all types of project members (top management, middle level management and lower level management, political leaders and services providers) should participate in the same manner only as carried out in this research.

This research includes only 317 numbers of public service participants in Sri Lanka. But in future researches the same success and failure factors could be measured in respect of all the public organizations that have introduced application of the cash management system. It is recommended that the suggestions given by the respondents be considered. Contacting political leaders and service providers of these projects and to identify their viewsand public-private partnership ine-cash management is an area yet to be re-searched. The differences between the e-cash management system in the public sector and the private sector organizations would be another area to be discussed in future. The comparison on public and private sector e-cash management is already available in literature, but in Sri Lanka, this type of published research articles is not traceable.

\section{References}

Agere, S. (2000). Promoting Good Governance, Principles, Practices, and Perspectives, Common Wealth Secretariat, Marlborough House, Pall Mall, London SW1Y 5HX. London. pp. 1-21, 41-61.

Allen, R., Schiavo-Campo, S., \& Garrity, T. (2004). Assessing and Reforming Public Financial Management: A New Approach. Washington: World Bank.

Chatterjee, S., Lubatkin, M. H., Schweiger, D. M., \& Weber, Y. (1992). Cultural Differences and Shareholder Value in Related Mergers: Linking Equity and Human Capital. Strategic Management Journal, 13(5), 319. https://doi.org/10.1002/smj.4250130502

Creswell, J. W., \& Plano Clark, V. L. (2011). Designing and Conducting Mixed Methods Research. Los Angeles: SAGE Publications.

Dillman, D. A. (2011). Mail and Internet Surveys: The Tailored Design Method-2007 update with New Internet, Visual and Mixed-Mode Guide. Retrieved from http://ECU.eblib.com.au/patron/FullRecord.aaspx?p=2815714

Fernando, R. L. S. (2005). Entrepreneurship in Delivery of Service in Public Sector Organization SriLanka: Prospects for Administrative and Management Reform, Workshop in Innovation in Governance and Public Service to Achieve a Harmonious Society, Annual Conference 2005.

Field, A. (2009). Discovering Statistics Using SPSS (3rd ed.). London: Sage.

Gonzalez, R., Gasco, J., \& Llopis, J. (2005). Information Systems Outsourcing Success Factors. Information Management and Computer Security, 13(5), 399-418. https://doi.org/10.1108/09685220510627287

Gunatunge, R. S. (2003). Habermasian way of Understanding Information Systems Development in Organizations in Sri Lanka, 9th International Conference on Sri Lanka Studies held at Matara, Sri Lanka.

ICT Policy document In Sri Lanka. Retrieved from http://www.icta.lk 
IMF Guidelines for Public Expenditure Management. (2005). International Monetary Fund. Retrieved from http://w.w.w.imf.org/external/pubs/ft/expend/guide5.htm

Kerlinger, F. N., \& Lee, H. B. (2000). Foundations of Behavioral Research: Wadsworth Thomson Learning.

Lienert, I. (2008). Public Financial Management, Technical Guidance Note, Fiscal Affairs Departments, IMF.

Mike, W. (2004). Government Cash Management—Good and Bad Practices, Technical Notes, pp. 2-21.

Ministry of Public Administration and Home Affairs Progress Report. (2015). And Activity Plan 2016.

Muttukrishna, S. (2007). The Government Budget (a Critical Appraisal with Reference to Transparency and Accountability, Pathfinder Foundation, Colombo, Sri Lanka, pp. 1-17.

Parente, P. P., \& Martinez-Mendez, P. (1995). Setting up a Treasury in Economics in Transition, IMF.

Ranasinghe, S., \& Fonseka, M. (2011). Research Methods in Management, Postgraduate Institute of Management, University of Sri Jayewardenepura. Colombo.

Rosen, H. (2002). Public Finance. Boston: McGraw-Hill.

Sekaran, U., \& Bougie, R. (2014). Research Method for Business (6th ed.). New York: John Wiley and Sons, Inc.

Simpson, S., Blizzard, L., Otahal, P., Ingrid Van der, M., \& Bruce, T. (2011). Latitude is Significantly Associated with the Prevalence of Multiple Sclerosis: a Meta-Analysis, JNNP Online First, and Published on April 8, 2011.

Smith, M. (2015). Research Methods in Accounting (3rd ed.). London: Sage.

Teofilovic, N. (2002). The Reality of Innovation in Government, Harvard Business Review, pp. 1-27.

The Central Bank of Sri Lanka, Annual Report. (2015). Colombo: Central Bank of Sri Lanka.

The Constitution of the Democratic Socialist Republic of Sri Lanka. (1978). The Department of Government, Printing, Sri Lanka. pp. 19-98.

Thong, J. Y. L. (1999). An Integrated Model of Information Systems Adoption in Small Businesses. Journal of Management Information Systems, 15(4), 187-214. https://doi.org/10.1080/07421222.1999.11518227

United Nations Project Office on Governance. (2010). An Inventory of Government Innovations and Good Governance in Asia, United Nations Department of Economic and Social Affairs, UNPOG Publication, Seoul, pp. 20, 43, 51, 124-182.

Wickramasinghe, I. K. (2003). Best Practices in the Public Sector. Sri Lanka Journal of Development Administration, 1, 85-105. The Sri Lanka Institute of Development Administration.

\section{Copyrights}

Copyright for this article is retained by the author(s), with first publication rights granted to the journal.

This is an open-access article distributed under the terms and conditions of the Creative Commons Attribution license (http://creativecommons.org/licenses/by/4.0/). 